\title{
TUNISIAN WOMEN, AT THE VANGUARD OF RESISTANCE ${ }^{1}$
}

\author{
Cécile Oumhani ${ }^{2}$
}

In October 2011, the Tunisian people were preparing for the first free elections after decades of dictatorship. They were still under the spell of what Western journalists referred to as the Arab Spring. The tyrant fled the country on January $14^{\text {th }} 2011$ after three weeks of peaceful protests that his police tried to crush with indiscriminate violence. Shooting people carrying their dead to the cemeteries did not deter the determination of citizens to do away with the regime. In the months that followed his departure, a general feeling of euphoria and freedom swept across the country. Women had been at the forefront of the revolution and many still claim in Tunisia that such a revolution would not have been possible, if women had not played such a prominent role from the very start.

Women in Tunisia have enjoyed the best status in the Arab world since the independence of the country. On August 13th 1956, President Bourguiba introduced the "Personal Status Code", which revolutionized Tunisian society. Polygamy was abolished, as well as unilateral repudiation. Mutual consent became necessary for a wedding to take place. The minimum age for marrying was raised. Wives no longer had any legal obligation of obedience to their husbands. They were now entitled to file for a

\footnotetext{
${ }^{1}$ Date of reception: 11/09/2013

Date of acceptance: $12 / 09 / 2013$

${ }^{2}$ Former Senior Lecturer at the Université de Paris-Est Créteil (UPEC), Cécile Oumhani is a poet and a novelist. Her most recent publications include award-winning novels Une odeur de henné (May 2012) and L'atelier des Strésor (August 2012). Tunisie, carnets d'incertitude (October 2013) is a testimony about the Tunisian revolution in the form of a diary. "Diary of the Tunisian revolution", a piece also about the Tunisian revolution, is due in Critical Muslim, issue 09, January 2014; $\square$ cecileoumhani@yahoo.fr.
} 
divorce and the law protected them, guaranteeing alimony and housing in case their marriage came to an end. At the same time, they were granted the right to work, to travel, to start a company, without asking for their husbands' permission. They also had access to contraception and abortion, without consulting their husbands.

In the years that followed the independence of Tunisia, women entered the workplace and gained unprecedented visibility in all spheres of society. They became lawyers, university professors and entered the police forces. Bourguiba personally encouraged women to unveil, using all sorts of derogatory expressions referring to the veil as "a miserable rag" or a "frightful shroud". He was filmed publicly removing the veils of a few radiant women. The role played by Bourguiba in introducing these unheard-of laws in the Arab world is essential.

However mention should also be made of other earlier historical figures, who paved the way for Bourguiba's "Personal Status Code". In pre-colonial Tunisia, a trend emerged for the modernization of the country as early as the $19^{\text {th }}$ century. After travelling to France, Grand Vizier Kheireddine Pacha opened the Sadiki College in 1875, a place where innovative methods were the rule: modern sciences and languages were taught. A new elite was formed at the Sadiki College: young men thirsting for changes in religion and later independence from the French protectorate, which began in 1881. Cheikh Mohamed Snoussi published a book advocating education for girls in 1897. At the turn of the century, Egyptian Princess Nazli Fazil (1853-1913) married a Tunisian and had a literary salon in La Marsa, not far from Tunis. She was known to have a correspondence with Lord Kitchener among others and she gave her support to the budding Tunisian nationalist movement. "L'Ecole de la Rue du Pacha", a school for girls was opened in 1900 thanks to the initiative of French Louise-Renée Millet. The pupils were recruited among upper class families, which were in favour of reform and modernity. In 1930, Tahar Haddad published a groundbreaking essay, Our Women in the Charia and Society, which infuriated the conservatives. Although his proposals were rejected by most in his lifetime, all of them were included twenty-five years later in Bourguiba's "Personal Status Code". 
Women themselves were not altogether absent from the public scene in this period. In 1936, Tawhida Ben Cheikh (1909-2010), a former pupil of the "Ecole du Pacha", became the first Tunisian woman gynaecologist, dedicating her competence to women. She became personally involved in the introduction of contraception in the wake of independence. In 1936, Bchira Ben Mrad (1913-1993) founded the first Tunisian women organization. She had not been given the possibility to attend a school but had received a private education at home from her father and a friend of his.

Looking back at the $19^{\text {th }}$ and $20^{\text {th }}$ century, it is obvious that the introduction of the "Personal Status Code" not only resulted from Bourguiba's action but also from a long fight started decades ago, by a few men as well as a few women who pursued their careers against the odds of tradition and conservatism. It could be added that Tunisia's pioneering position in the Arab world is equally notable in such measures as the abolition of slavery in January 1846, a measure unheard-of at the time in any other part of the region. Tunisia was also the first Arab country to promulgate a declaration of the rights of the citizen, the Fundamental Pact or Ahd el Amen in September 1857, which guaranteed the equality of all citizens, whatever their religion or ethnic origin. It was the first Arab country to have a written constitution in 1861. These dates have their importance, whatever could be said about the actual implementation of all these texts in the subsequent years. Is it a surprise that Tunisia was also the first country in the region to start its revolution in December 2010? These moments in history reveal an inheritance quite different from what the obscurantist discourse of religious parties would want it to be. Present Tunisian civil society emerged from a past marked by a deep-seated quest for reform and modernity.

In October 2011, who thought Islamist party Ennahdha would win the election for the Constituent Assembly? In the euphoria that followed the fall of the regime, over 110 different political parties were born. None of them apparently stopped to think about the threat represented by one party who had been conspicuously absent from the protests in the streets. And yet Ennahdha had secretly been on the political scene for a quarter of a century. Its militants had been jailed and persecuted. Retrospectively it is easy to understand how they cashed in on Ben Ali's corruption. Among the people, they 
had the aura of those who had suffered at the hands of Ben Ali's police. Moreover they were religious and for a number of voters this gave them the credit of honesty. How could religious people rob the country as the former ruler had done for years with the members of his family?

With over 110 different parties running, it was not difficult for them to win the election. They obtained $41,47 \%$ of the votes with only $50 \%$ of the electorate casting their ballots. Their victory put a damper on the enthusiasm that prevailed throughout the first months of the revolution. A coalition government was formed, called the "troika".

Over the following weeks and months, society started changing. Extremist Salafi groups appeared on the scene, with Ennahdha claiming it had nothing to do with them, but always giving the impression that if they were unable to control them, it was very likely they condoned their action. These groups made their presence felt through violent actions here and there, against bars and hotels selling alcoholic beverages, against individuals suspected of drinking, against women not dressing according to their codes.

They perpetrated attacks against a TV channel in October 2011 for showing Persepolis, the film based on Iranian Marjane Satrapi's autobiographical graphic novel. Nabil Karoui, the head of Nessma, was tried for "insulting sacred values" and was heavily fined, while his attackers went free. In September 2012, the Salafis attacked the American Embassy in Tunis, causing the death of two persons. The court's leniency towards them has shocked more then one.

Not only do some women feel insecure enough in some districts to wear a "hijab", when they never did in the past, but customary marriage is also spreading in underprivileged areas and universities, promoted by Salafi groups. This kind of marriage or "orfi" marriage only requires the presence of two witnesses and a pseudomarriage contract. Women are easy victims for this kind of marriage and many have already fallen prey to false promises. Still illegal in Tunisia, it would mean a serious retrograde move, if generalized and institutionalized. It undoubtedly reflects the impact of Salafi ideas among young people in some parts of the country. 
It is to be noted that more and more religious kindergartens are opening all over the country, raising serious concern about the future of education in a country where the schooling-system had always been organized inside a secular frame. Furthermore it had been illegal for women working in schools and administrations to wear veils. In November 2011, very serious incidents broke out at the Faculty of Arts in La Manouba, where Salafis demanded the right for women students to attend classes and sit exams wearing "niqabs". Until the revolution, such outfits were unknown in Tunisia; the previous regime had outlawed such outfits, as well as growing Islamist beards. Habib Kazdaghli, the Dean, courageously stood up against the Salafis and was taken to court, falsely accused of molesting two students dressed with "niqabs". Although petitions and various actions were organised in his favour, the court decided he was innocent, it may well be that students will obtain the right to wear "niqabs" on university grounds, a serious defeat for women and the values of modernity.

Ever since Ennahdha has been in power, women have been especially attentive to debates and decisions going on in the Constituent Assembly. They have worried about threats against the "Personal Status Code". And rightly so, as revealed the plan to define woman as "man's complement" in the new Constitution, thus erasing the principle that made men and women equals. When this transpired in the course of Summer 2012, the civil society immediately took to the streets until it was decided that equality would remain, as it is written in the 1956 Constitution.

The general situation of the country has been steadily deteriorating, marked this year by the assassination of two leaders of the Opposition. Chokri Belaïd was shot down, as he left his home, on February $6^{\text {th }}$ 2013. Mohamed Brahmi was gunned down in front of his children on July $25^{\text {th }}$ 2013. Further plots to assassinate other leaders, among them women, have been discovered. To this day, the assassins have not been arrested.

Tunisia is not used to such violence and people have been in a state of shock since these tragic events. They have massively demonstrated all over the country, calling for a general strike in both cases, to express their disgust and horror. Women have not been among the last to voice their revolt. Chokri Belaïd's widow, Basma Khelfaoui went out 
into the streets of Tunis, on the morning of his death, raising her hand in the sign of victory, becoming a symbol of courage and resistance. She was followed by thousands of women, who broke with Tunisian tradition on February $8^{\text {th }} 2013$, the day Belaid was buried. It had not been done for women to attend a funeral, even for the closest family relatives, on the grounds that females were not morally strong enough to bear such a ceremony. It has been observed that Basma Khalfaoui and Tunisian women resolutely rejected such segregation last February, asserting through their presence that they are men's equals in all aspects of life.

When Mohamed Brahmi was assassinated, sit-ins were organised at the Bardo, where the Constituent Assembly is based. A number of members withdrew, thus bringing the drafting of the Constitution to a halt. They have not resumed their work since August and have been demanding the resignation of the government. On October $6^{\text {th }} 2013$, the government announced that it would leave and promised that a new team of technocrats would be appointed to run the country. In other words, Tunisian civil society's proactive attitude has been paying and it is still too early to say that the 2011 revolution is over or that its ideals have been confiscated.

I will take another significant example to show that deep changes are still going on inside Tunisian society. It will also illustrate how two contradictory trends are running through the country. In March 2013, 18-year-old Amina Sboui posted on Facebook a photo of her naked torso with a sentence written across her breasts. It read: "My body belongs to me and it is the honour of no one". At the time, she claimed to have joined the Ukraine-based Femen movement, which she has since left. Her photo unleashed hatred, the vilest insults and threats against her. Her page was hacked by Salafis. A Salafi preacher was invited to a talk show, two days after she had spoken on the same programme. He refused to sit on the seat assigned to him, saying the chair was impure after she had sat there. He added that she deserved to be flogged if not lapidated. Amina's photo not only infuriated fundamentalists, it also revealed how conservative many parts of society still are. It soon transpired that even feminists and modernists frowned upon her action and would not support her. 
On May $19^{\text {th }} 2013$, the Congress of Salafi Ansar Echcharia was to be held in Kairouan, a holy city in the centre of the country. Amina made it known that she would go and confront them. Film director Nadia El Fani tried to talk her out of going, saying they would lynch her and that if she really wanted to go, she had to do it in the presence of a few journalists. She went alone all the same, bravely determined to oppose these extremists, carrying self-defence spray in her backpack. The police promptly arrested her, taking her to jail for being in possession of illegal weapons and desecrating a cemetery. It turned out that she had painted the word "Femen" on the wall separating the street from the cemetery. Painting slogans on walls everywhere in the country had been common practice ever since the revolution. Amina's arrest made it impossible for the 18-year-old girl to sit her final secondary school exams. She was jailed in horrendous conditions for over two months, confined in 20-square-meter cell with fortyfive other inmates. She was only released a few days after the assassination of Mohamed Brahmiat the beginning of August and now lives in France where she is trying to start a new life.

Interestingly enough, throughout the weeks of her imprisonment, Tunisian society changed its attitude towards her. The feminists and modernists who had criticized her started supporting her and asking for her liberation, widely approving the action initiated by the committee set up for her liberation. Amina's act of rebellion is much more than the anecdotal behaviour of a teen-ager. In the context of a country where women have adopted "niqabs", her gesture is a symbol of bravery. The sentence she wrote across her breasts is loaded with meaning. "My body belongs to me. It is the honour of no one else", it said. Amina was thus asserting her right to use her body as she wanted to. She was also claiming her own existence, as a being separate from any group, emerging freely and independently from the straightjacket of the traditional Mediterranean family. Amina embodies change, new lifestyles to come, as well as resistance against the obscurantist forces at work in Tunisian society, in a process that is bound to take a long time.

Tunisian women are concerned about their daughters' future and they are determined to take any action needed to defend the status they were given in 1956. Young Amina 
embodies a new generation who saw the revolution as the promise of even further perspectives for change. She may have been alone, as she was last March, when she posted her photos on Facebook. Yet, it is probably no coincidence that in Egypt Aliaa el Mahdy also posted a full picture of herself naked on her blog. Activist Lina Ben Mhenni posted a picture of her naked back in August 2010. These young women, in different places, at different moments, each expressed their desire to rid themselves of the past and redefine their relationships to themselves and the outside world. This period is certainly not an easy one, as the situation seems to be constantly fluctuating. But is this really surprising? Revolutions have always implied the opposition of conflicting trends. Lasting change simply cannot follow the pace of the Internet messages that brought recent events of the so-called Arab Spring to the knowledge of the whole world. History bides its time, while also requiring the constant vigilance of its actors. 